DOI: https://doi.org/10.3126/njdrs.v18i01.41942

\title{
Rural Revitalisation Process of Nation-Building in Nepal
}

\author{
Prajwal Man Pradhan ${ }^{1}$, SubhashJha ${ }^{2}$ \\ ${ }^{1}$ Lecturer at Central Department of Rural Development, Tribhuvan University, Nepal \\ ${ }^{2}$ Lecturer, Ratna Rajya Laxmi Campus \\ Correspondence should be addressed to: prajwal.pradhan@cdrd.tu.edu.np
}

\begin{abstract}
Government of Nepal has been trying to revitalize rural areas after 1950s as a strategy of nationbuilding. The demands of ethnic groups are basically inclined with quest for ethnic identity, equality, and greater representation in the political structure. Among the ethnic groups, the largest groups are Janajati, Madhesi and Dalits. In this stance, this library based study tried to look at problems and prospects of balance development as an outcomes of revitalization process of nation-building. At the same time the study also tried to identify essential driver of rural revitalization in Nepali context. The study found that equal distribution of development is difficult in terms of its social, regional and cultural diversity. Poverty, unemployment, landlessness, rapid population is major push factor in Nepal to overcome from this problem. Besides these problems there are some prospects through which rural setting can be revitalized economically, socially, politically such as agriculture. One essential driver of rural revitalization is rurbanomics, an approach that emphasizes the linkages between rural and urban economies. Growing urbanization in most countries enhances the importance of rural areas-by boosting demand for food, diverse diets, and goods and services that the rural economy can meet. Rurbanomics, therefore, frames rural and urban economies as equal partners. Ending hunger and malnutrition to achieve both the Sustainable Development Goals and climate goals requires us to initiate a range of evidence-based actions to advance rural revitalization in all regions of the world. Rural revitalization represents the most realistic way to achieve such a dramatic transformation to ensure that rural people and rural areas can thrive for generations to come.
\end{abstract}

Key words: Nation, urban, rural, revitalization, rurbanomics, Nepal

\section{Background}

Nepal, the landlocked multiethnic, multilingual, multi-religious country, has geographically three elongated ecological belts. Looking back to its history, the monarchy had played a central role in the unification and evolution of Nepali state. Prithvi Narayan Shah, the king of Gorkha principality, established modern unified Nepal by conquest. He, thus, introduced the Shah regime based on the right of sword. In the post-unification period, "the process of Hinduization was intensified" (Baral, 1991, p. 56). So the kingship along with the Hindu religion played a key role in the construction of Nepali state and identity (Hachhethu, 2003).Nepal's diplomacy during the unification era was basically guided by military doctrine. Nepal during the unification era followed military diplomacy and had a little time to spare for other aspects of diplomacy. The concept of 'yam' and 'equidistance' coined by Prithvi Narayan Shah was the diplomacy based on military doctrine, which was necessary at that time when Nepal was a military state. The 'yam and equidistance' concept has guided Nepalese diplomacy even today, although this concept has a little relevance in the 21st century's democracy. But Prithvi Narayan Shah's other 'wise counsels' continue to provide an important basis for Nepal's foreign policy and diplomacy even today (UKEssays, 2018). The Hindu polity - in which monarchy and religion have decisive role - was further enacted more rigidly during the Rana period (1846-1951).

According to the 2001 national census, ninety two different living languages are spoken in Nepal (a ninety third category was "unspecified"). Based upon the 2011 census, the major languages spoken in Nepal are Nepali, Maithili and Bhojpuri (CBS, 2011).Since Nepal's unification, various indigenous 
languages have come under threat of extinction as the government of Nepal has marginalized their use through strict policies designed to promote Nepali as the official language. Indigenous languages which have gone extinct or are critically threatened include Byangsi, Chonkha, and Longaba. Since democracy was restored in 1990, however, the government has worked to improve the marginalization of these languages. Tribhuvan University began surveying and recording threatened languages in 2010 and the government intends to use this information to include more languages on the next Nepalese census (Tumbahang, 2010).

The Constitution of Nepal (2015) has declared the country a Federal Democratic Republic with seven Provinces. It is further divided into 753 local levels including 460 Rural Municipalities, 276 Municipalities, 11 Sub-metropolitan Cities and 6 Metropolitan Cities. There are 77 administrative districts in Nepal. Nepal is among the richest in terms of water resource availability and it is one of the most important natural resource of the country. Water resources are abundant throughout the country in the form of snow covers, rivers, springs, lakes, and groundwater. Among them, rivers are the most important water resources in Nepal. The major rivers in Nepal are Mechi, Koshi, Bagmati, Narayani, Gandaki, Kanali and Mahakali. The total renewable water resource of the country is estimated to be 237 $\mathrm{km} 3 /$ year $(225 \mathrm{~km} 3 /$ year for surface sources and $12 \mathrm{~km} 3 /$ year for groundwater sources) and per capita water availability for 2001 was $9600 \mathrm{~m} 3 / \mathrm{capita} /$ year. Nepal has a huge hydropower potential. In fact, the perennial nature of Nepali rivers and the steep gradient of the country's topography provide ideal conditions for the development of some of the world's largest hydroelectric projects in Nepal. Current estimates are that Nepal has approximately 40,000 MW of economically feasible hydropower potential. However, the present situation is that Nepal has developed only approximately 1299 MW of hydropower. Although bestowed with tremendous hydropower resources, only about $90 \%$ of Nepal's population has access to electricity (MoF, 2021).

About 37.8 percent of its population reside in rural areas and estimated around 16.67 percent are absolute poor (Economic survey, 2019/2020). The economic survey of 2018/19 highlights that the annual economic growth has remained 4.6 percent on an average in the last decade. In this period, the average annual growth rate of agriculture and non-agricultural sector remained 3.1 percent and 5.3 percent, respectively. The contribution of service sector activities to gross domestic products (GDP) is 71.9 percent while the contribution of agriculture sector is 28.1 percent in the fiscal year 2018/19.The poverty rate of some disadvantaged groups, Dalits and women is almost double that of the national average, with many of the rural poor relying on temporary or long term labour migration as their livelihood strategy. Development assistance, tourism, the export of carpets and garments, as well as the remittances of millions of Nepalese working abroad, play an important role in the Nepalese economy. According to the population composition of Nepal, about 500 thousand persons are entered to the labor market every year. Due to lack of employment opportunities in the country, attraction of foreign employment is still high. About 4.30 million youths have gone abroad in foreign employment through formal and informal way. According to the latest labor force survey, unemployment rate in Nepal is 11.4 percent.

\section{Problems}

Rural areas are in crisis. Rural residents make up 45 percent of the world's population but bear a disproportionate burden of poverty, malnutrition, and poor quality of life. The global rural poverty rate is 17 percent (compared to 7 percent in urban areas). Rural people comprise 70 percent of the world's extremely poor. Rural areas lag behind urban areas in reducing rates of child stunting (low height for age). Many rural environments lack basic services such as education; health; roads; water and sanitation; and suffer from rising pollution levels and dwindling natural resources. These challenges will only be exacerbated by climate change. As the deadlines to achieve the Sustainable Development Goals (SDGs) and climate goals draw ever closer, it is time for a dramatic, system-wide transformation to make rural areas more productive, sustainable, climate-resilient, healthy, and attractive places to live in order to leave no one behind(IFPRI, 2019).

Hachhethu in his article had highlighted that ethnic upsurge is inevitable in Nepal as the historical process of national integration is exclusionary. The restoration of democracy with the principles of 
popular sovereignty, equality, freedom and cultural rights has provided platform for ethnic activism. The advent of democracy has, therefore, been followed with the rise of ethnic consciousness and awareness. The ethnic issue has gained a new weight and strength because of the impact of the Maoist's armed insurgency. Among the ethnic groups of Nepal, the largest groups are Janajati, Madhesi and Dalit.The demands of ethnic groups can broadly be categorized into three areas: quest for identity, equality, and greater representation in the political structure. Government of Nepal has tried to adopt rural development approach for the development of rural areas after 1950s and as a strategy of balanced development and nation building. Unfortunately, equal distribution of development is difficult in terms of its social, regional and cultural diversity. National Economic Census (2018) reveals that nearly 40 percent of largescale establishments and more than one third of medium-scale establishments are located in Kathmandu Valley. Nearly 40 percent of medium-scale establishments and 14.9 percent of large-scale establishments belong to "Education". Poverty, unemployment, landlessness, rapid population is major push factor in Nepal, to overcome from these problems, people choose place where there is better facility of education, welfare systems, good environmental and living conditions which is consider as pull factors.

\section{Prospects}

Although agricultural production is critical to rural economies, rural revitalization goes far beyond agriculture as it includes the development of non-farm opportunities and it makes cutting-edge technology and innovation the linchpins of rural economic growth. Rural revitalization can also dramatically improve rural residents' access to basic services. In Bangladesh, for example, improved rural roads reduced extreme poverty by 3 to 6 percent while boosting enrolment in secondary school for both boys and girls. Rural development in Nepal is a complex phenomenon involving an interaction of economic, social, political and cultural factors leading to national integration and nation building. The concept of rural development is a process of development and change to improve rural social life entirely. It is linked to infrastructural development, commercialization of agriculture, proper utilization and mobilization of resources, food security, creating opportunities, inclusive social development in the rural community and modernization of overall society. However, achievements of rural development efforts in Nepal are not satisfactory because of imposed development, unstable political situation, absence of people's participation, lack of research and political commitment.

The World Bank in its feature story 'Managing Nepal's Urban Transition' highlights three things. First, a predominantly rural country, Nepal is urbanizing rapidly with urban population growth rates of up to 7 percent. Second, the sustainability of urbanization in Nepal is threatened by a lack of effective planning and large and growing infrastructure deficits. And third, Nepal's urban areas can drive economic growth to the benefit of the entire country. For this, Nepal needs to prioritize the "where, what, and how" of public investments based on development outcomes, promote the development and regeneration of the Kathmandu Valley, and enhance the competitiveness of strategic clusters - such as cultural tourism, handicrafts, and agro-processing - to foster sustainable growth and create economic opportunities in urban areas.

Rural revitalization can also improve rural governance, ensuring that local governments are held accountable in the delivery of high-quality services. China chose this approach when it announced a new strategy in 2018 to close the growing rural-urban income gap and improve quality of life in rural areas. One essential driver of rural revitalization is rurbanomics, an approach that emphasizes the linkages between rural and urban economies (GFPR, 2021). Growing urbanization in most countries enhances the importance of rural areas - by boosting demand for food, diverse diets, and goods and services that the rural economy can meet. Rurbanomics, therefore, frames rural and urban economies as equal partners. It empowers rural economies not only as drivers of food security but also as springboards for national, regional, and global value chains and as providers of quality environmental services.

Ending hunger and malnutrition to achieve both the Sustainable Development Goals (SDGs) and climate goals requires us to initiate a range of evidence-based actions to advance rural revitalization in all regions of the world. They include: 
- Adoption of rurbanomics as an approach to strengthen rural-urban linkages-not only between rural areas and megacities, but also between small rural population centers.

- Transforming agri-food systems to benefit both rural and urban areas. Agriculture must be seen as a business enterprise that can feed all.

- Scaling-up agricultural productivity and investing in the rural non-farm economy to create wageearning opportunities, particularly for poor, female- and youth-headed households.

- Improving living conditions in rural areas, by providing better access to social safety nets and basic services and supporting a healthier and more climate-resilient environment. Multiple models exist laying out ways to successfully and affordably provide these services, while improving the use of natural resources.

- Reforming rural governance to improve accountability and outcomes through well-funded rural budgets, capable staff, and transparency.

Rural revitalization represents the most realistic way to achieve such a dramatic transformation to ensure that rural people and rural areas can thrive for generations to come. For example, rural tourism can play a significant role. According to World Travel and Tourism Council (WTTC)'s annual Economic Impact Research report for 2017, tourism accounts for 7.5 percent of Nepal's GDP and is forecast to rise 4.3 percent annually to Rs287.6 billion, or 8.3 percent of the GDP in 2027. The GDP generated directly by the travel and tourism sector includes its indirect and induced impacts. Nepal's travel and tourism sector pumped Rs177 billion into the economy and supported more than 427,000 jobs last year.

\section{Case Study: China's Rural Revitalization Strategy}

Urbanization in China has made unprecedented progress, bearing witnesses to the country's transition from a traditional big agricultural nation to a modern manufacturing power. China's once backward rural society is turning into an affluent urban one. Based on the report, China's urbanization rate has increased 58.5 percent with an average annual growth of 16.4 million urban people. It has made a great contribution of 25.6 percent increase in world population in the past 40 years. However, rapid urbanization also accompanied some adverse impact on social productivity improvement and limited resources distribution. One obvious phenomena of urbanization is traffic congestion that's barely seen in villages (BFA, 2019).Since reform and opening up, the development of Chinese urban and rural areas has shown an evolution of integration from isolation. The government promulgated national policies and related planning strategies, aiming at realizing the goal of rural revitalization through the system reform and planning adjustment of balancing urban and rural development. In the complex process of social development, there are many problems with rural areas, such as lack of infrastructure, unbalanced economic development, dilapidated living environment and insufficient sharing between urban and rural areas. On the premise of meeting the requirements of national laws and policies, this paper takes the planning of Batang village in Yunfu city of Guangdong province as an example. Combine with ReBAM theory to make sure Batang village is suit for developing tourism. And based on field survey made a Batang plan by planning knowledge. Through literature review and field survey to explore how to realize the revitalization of the rural areas under the development mode of balancing urban and rural development.

The conclusion of the research took rural tourism as the breakthrough point, and formed complementary and dislocation development mode with the city. In living aspect, the research optimized infrastructure and improved people's living environment as well as summarized cultural elements to inherit rural civilization. In production aspect, it exploited rural commercial potential and incomegenerating path, and completed the transformation from passive development to active revitalization to achieve prosperity industry and life. In ecology aspect, it combined with sustainable development model to create an ecological and livable rural landscape. At last, the research established urban and rural comanagement system and shared rural information platform to achieve effective governance, to ensure that tourism mode as a starting point for rural revitalization planning can be sustainable development. The research of this paper practiced the national experience of rural revitalization as a pilot project, facilitated 
the implementation of relevant policies and supported planning for rural revitalization, and explored the methods of rural revitalization under the background of balancing urban and rural development (Guo, $\mathrm{Li}$ \& Zhang, 2019). In 2017, Chinese President Xi Jinping first put forward the idea of "implementing the strategy of rural revitalization" during the 19th CPC National Congress, and called it a major strategy with fundamental impact on national livelihood and nation building(CGTN, 2019). With the rise of industrialization and urbanization, rural areas in developing countries are inevitably suffering from downfall and depression. How to strike a balance between urbanization and rural development and income inequality has been the biggest question for many countries for decades. The report highlights the essence of rural revitalization to ensure that the benefits of development and growth reach all citizens.

\section{References}

Central Bureau of Statistics [CBS]. (2011). Official summary of population census. Government of Nepal. Guo, W., Li, B., \& Zhang, Y. (2019). Rural revitalization under the background of balancing urban and rural development: A case study of Batang village, Guangdong Province, China

Hachhethu, K. (2003). The Question of Inclusion and Exclusion in Nepal Interface between State and Ethnicity. Paper presented to the Conference on "The Agenda of Transformation: Inclusion in Nepali Democracy" organized by Social Science Baha on 24-26 April, 2003 at Birendra International Convention Centre.

UKEssays (November 2018). History of military diplomacy in Nepal. https://bit.ly/32Kgy9i

Global Food Policy Research [GFPR]. (2021).Rural revitalization: Tapping into new opportunities. http://gfpr.ifpri.info/2019/03/26/chapter-2-rural-revitalization

Ministry of Finance [MoF]. (2021). Economic survey (2020/21). Government of Nepal.

Swiss Re Institute (March, 2020). Rural revitalization: extending the reach of insurance across China's rural areas.

Tumbahang, G. B. (2010). "Marginalization of indigenous languages of Nepal". Contributions to Nepalese Studies. 37, 69 - via Expanded Academic.

Yin,X., Chen,J., \& Li, J. (2019). Rural innovation system: Revitalize the countryside for a sustainable development. Journal of Rural Studies.doi: 10.1016/j.jrurstud.2019.10.014

InternationalFood Policy Research [IFPRI]. (2019). A global rural crisis: Rural revitalization is the solution. https://bit.ly/3mLgVYh

Boao Forum for Asia [BFA]. (2019). A sustainable future for rural Asia and cities (March 2019). https://bit.ly/3JrgFYd

Guo, W., Li, B. \& Zhang, Y. (2019). Rural revitalization under the background of balancing (urban and rural development: A case study of Batang village, Guangdong province, China. 55th ISOCARP World Planning Congress in Jakarta/Bogor, Indonesia 09 September - 13 September 2019.

China Global Television Network [CGTN]. China steps up rural revitalization for new future urban zones. https://bit.ly/3HmMWOf 